\title{
Tingkat Kebutuhan Guru Paud Terhadap Penggunaan Google Classroom Selama Masa Pandemi
}

\author{
Wan Nova Listia \\ Dosen Program Studi PG PAUD FIP UNIMED \\ Jl. Williem Iskandar Pasar V Medan Estate, Medan, Sumatera Utara,20371 \\ Email: wannova.listia@gmail.com
}

\begin{abstract}
Abstrak: Penelitian ini bertujuan untuk melihat seberapa jauh guru PAUD membutuhkan metode pembelajaran daring selama masa pandemic ini. Penggunaan Google classroom sebagai salah satu strategi untuk membantu guru PAUD dalam melaksanan kegiatan belajar mengajar. Jenis penelitian ini adalah deskritif kualitatif. Data penelitian diperoleh dengan cara pembagian angket dan wawancara kepada guru PAUD. Berdasarkan hasil analisis data maka dapat disimpulkan bahwa Google Classroom dapat menyediakan wadah atau tempat untuk menyampaikan materi yang mampu mengurai konsep bersifat abstrak dan rumit. Sebab, materi dan konsep yang rumit lebih mudah diuraikan melalui bahan ajar audio-visual.
\end{abstract}

Kata Kunci: guru PAUD, Google Classroom, masa pandemi

\section{Pendahuluan}

Setelah munculnya wabah Covid-19, sistem pendidikan mulai mencari suatu inovasi untuk proses kegiatan belajar mengajar. Sebagai upaya untuk mencegah menyebarnya wabah tersebut, maka pemerintah mengeluarkan kebijakan agar sekolah-sekolah meminta siswanya untuk belajar di rumah. Surat Edaran no. 4 tahun 2020 dari Menteri Pendidikan dan kebudayaan yang menganjurkan seluruh kegiatan di institusi pendidikan harus jaga jarak dan seluruh penyampaian materi akan disampaikan di rumah masing-masing.

Pembelajaran daring adalah layanan bantuan belajar di saat ini yang semakin populer dan diandalkan dalam metode pembelajaran jarak jauh. Sistem pembelajaran daring (dalam jaringan) merupakan sistem pembelajaran tanpa tatap muka secara langsung antara guru dan murid tetapi dilakukan melalui online yang menggunakan jaringan internet. Guru harus memastikan kegiatan belajar mengajar tetap berjalan, meskipun siswa berada di rumah. Solusinya, guru dituntut dapat mendesain media pembelajaran sebagai inovasi dengan memanfaatkan media daring (online). Guru harus mampu membuat model dan strategi pembelajaran yang sesuai dengan karakter murid di sekolahnya. Penggunaan beberapa aplikasi pada pembelajaran daring sangat membantu guru dalam proses pembelajaran ini. Guru harus terbiasa mengajar dengan memanfaatkan media daring kompleks yang harus dikemas dengan efektif, mudah diakses, dan dipahami oleh siswa.

Salah satu aplikasi yang dapat membantu guru untuk menyampaikan pembelajaran pada murid/ orangtua murid yaitu melalui google classroom. Aplikasi Google Classroom memberikan kebermanfaatan dengan berbagai 
kemudahan kepada murid untuk memahami materi pelajaran dengan cara kemudahan dalam membaca materi pelajaran, membaca power point yang diberikan oleh guru, melihat video terkait dengan pembelajaran sehingga siswa dapat belajar dimana saja dan kapan saja, tidak hanya belajar di kelas.

Tetapi masih banyak guru Paud yang mengalami kesulitan dalam meningkatkan efektivitas pembelajaran murid saat ini, hal ini dikarenakan ketidaktahuan guru dalam menggunakan metode pembelajaran daring yang tersedia. Jika tanpa disertai bahan ajar yang lengkap yang salah satunya berbentuk materi pengayaan yang berbentuk multimedia interaktif, akan sulit bagi guru untuk meningkatkan motivasi belajar murid. Sehingga proses pembelajaran yang diperoleh murid tidak optimal. Murid tidak mendapatkan pengalaman pembelajaran yang baik dan dikhawatirkan akan memengaruhi hasil aspek perkembangan mereka.

Untuk itu pemanfaatan blended learning "google classroom” merupakan salah satu aspek penting untuk menciptakan proses pembelajaran yang berkualitas di PAUD. Sehingga, guru PAUD selalu dituntut untuk menguasai teknologi yang berkualitas dan inovatif. Dengan penguasaan teknologi yang berkualitas tersebut akan menciptakan sebuah kondisi positif, di mana orangtua dan murid termotivasi untuk terlibat pada proses pembelajaran. Sehingga diharapkan hasil pembelajarannya memuaskan, sesuai dengan tujuan dibuatnya pelatihan ini. Peneliti menemukan bahwa masih banyak guru PAUD yang mengalami kesulitan dalam menemukan metode yang tepat untuk melaksmuridan kegiatan belajar mengajar dimasa pandemic ini. Dengan adanya perkembangan teknologi dibidang pendidikan memberikan kemudahan bagi guru dan murid dalam proses belajar mengajar.

\section{Kajian Teori}

Pada masa pandemic seperti sekarang ini, guru dituntut untuk kreatif dalam menggunakan teknologi yang berkembang pesat. Seiring dengan perkembangan teknologi, maka media pembelajaran pun mengalami perkembangan melalui pemanfaatan teknologi yang berkembang. Adapun manfaat atau dampak dalam penggunaan media dalam proses pembalajaran menurut Arsyad (2000) diantaranya:

1. Penyampaian pelajaran menjadi lebih bak.

2. Pembelajaran bisa lebih menarik.

3. Pembelajaran menjadi lebih interaktif.

4. Lama waktu pembelajaran yang diperlukan dapat dipersingka5.

5. Kualitas hasil belajar dapat ditingkatkan.

6. Pembelajaran dapat diberikan kapan dan di mana dinginkan atau diperlukan.

7. Sikap positif siswa terhadap apa yang dipelajari \& proses belajardapat ditingkatkan. 
8. Peran guru menjadi lebih positif, beban guru untuk penjelasan yang berulang-ulang mengenai isi pelajaran dapat dikurang.

Proses pembelajaran sesungguhnya memiliki peran penting dalam upaya meningkatkan kualitas pendidikan, sehingga pembelajaran yang diselenggarakan dengan mengedepankan kebermaknaan dan kemanfaatan bagi murid. Pembelajaran dalam jaringan telah memungkinkan proses belajar menjadi lebih luas, lebih interaktif dan lebih fleksibel. Di dalam bidang pendidikan guru dapat merasakan kebermanfaatan teknologi tersebut melalui suatu media pembelajaran di kelas, media tersebut berupa sebuah aplikasi yang dapat membantu guru dalam menyampaikan materi belajar kepada murid. Guru dan murid dapat melakukan proses belajar mengajar tanpa di batasi oleh ruang dan waktu, artinya jika ada fasilitas jaringan, peserta didik dapat melakukan proses belajar di mana saja dan kapan saja. Aplikasi Google Classroom merupakan layanan berbasis internet yang disediakan oleh Google sebagai sebuah aplikasi e-learning (pembelajaran dalam jaringan).Google Classroom adalah bagian dari $\mathrm{G}$ Suite for Education yang juga hadir dalam versi aplikasi seluler. Menurut Iskandar (2020) Googleclassroom atau dalam bahasa Indonesia yaitu ruang kelas google adalah sebuah serambi pembelajaran yang dapat diperuntukan terhadap ruang lingkup pendidikan yang dimaksudkan untuk membantu menemukan jalan keluar atas kesulitan yang dialami dalam membuat penugasan tanpa menggunakan kertas (paperless).

Adapun kegunaan google classroom yaitu: a) penyiapan yang mudah, guru dapat menambahkan siswa secara langsung atau berbagi kode dengan kelasnya untuk bergabung pada kelas online, hanya perlu beberapa menit untuk menyelesaikannya, b) hemat waktu, alur tugas yang sederhana dantanpa menggunakan kertas memungkinkan guru membuat, memeriksa, dan menilai tugas dengan cepat dalam satu tempat, c) meningkatkan pengorganisasian, siswa dapat melihat semua tugas hanya dalam satu laman tugas, dan semua materi kelas secara otomatis tersimpan kedalam media penyimpanan online, d) meningkatkan kerja sama dan komunikasi, kelas dapat digunakan oleh guru untuk mengirim pengumuman dan memulai forum diskusi secara langsung. Siswa dapat saling berbagi informasi sumber daya satu sama lain atau memberikan jawaban atas pertanyaan dialiran ( Khairunnisa, 2020)

Untuk menggunakannya, guru dan murid wajib memiliki akun Google agar saling terhubung. Google Classroom merupakan sebuah aplikasi yang memungkinkan terciptanya ruang kelas di dunia maya. Selain itu, google classroom bisa menjadi sarana distribusi tugas, submit tugas bahkan menilai tugas-tugas yang dikumpulkan. Jika ingin menggunakan google classroom, maka terlebih dahulu para murid dan guru harus memiliki akun Google. Dalam mendaftarkan akun Google ini bisa melalui smartphone maupun laptop. Via aplikasi maupun browser konfigurasinya hampir sama dan mudah. 
Berikut tahapan penggunaan google classroom:

1. Buka Browser (Google Chrome, Mozilla Firefox, Microsoft Edge)

2. Ketikkan Google Classroom di Search Engine atau ketikkan https://classroom.google.com/

3. Pilih Akun Google dan Daftarkan pada tahap Sign Up

4. Klik Continue untuk melanjutkan

5. Selanjutnya, untuk Guru, Klik tanda (+) di pojok kanan atas

6. Pilih Create Class untuk membuat kelas pertama Anda

7. Selanjutnya lakukan Konfigurasi mengenai informasi kelas

8. Isi Nama Kelas yang akan dibuatkan, Klik Class Name dan masukkan detailnya.

9. Dalam menambahkan informasi deskripsi singkat, tingkat kelas, atau jadwal kelas, Klik Section dan masukkan detailnya.

10. Dalam menambahkan Subject atau mata pelajaran yang akan diajar. Klik Subject dan Masukkan detailnya.

11. Dalam menambahkan lokasi kelas. Klik Room dan Masukkan detailnya.

12. Klik Create, untuk membuat Kelas

13. Halaman Kelas akan terlampir

14. Perhatikan Class Code yang digunakan siswa agar bisa bergabung ke kelas yang telah dibuat.

15. Untuk Membuat Tugas Kelas, Klik Classwork pada menu atas.

16. Klik Create, Pilih jenis tugas yang akan dibuat

17. Pilih Assignment jika ingin membuat tugas, Klik Assignment

18. Klik Title, Masukkan detail Judul Tugas.

19. Klik Instruction, Masukkan Informasi tentang tugas maupun Instruksi.

20. Klik Add, untuk menambahkan materi pelajaran yang disiapkan atau Tekan Create jika baru ingin membuatnya

21. Selanjutnya di Jendela kanan atas, Atur Points, Tenggat Waktu, Topik, dan Rubrik.

Pembelajaran melalui google classroom merupakan bagian dari strategi dalam memanfaatkan teknologi sehingga dapat memudahkan guru dan murid/ orangtua dalam proses pembelajaran. Melalui google classroom ini, guru dapat memberikan materi seputar pelajaran yang diajarkan, baik itu menyajikan materi, memberikan tugas maupun mengunggah nilai murid sehingga murid/ orangtua langsung dapat melihat nilai tersebut.

\section{Metode Penelitian}

Metodologi dalam penelitian ini bersifat deskriptif dengan pendekatan kuantitatif. Metode deskriptif adalah prosedur pemecahan masalah yang diselidiki dengan menggambarkan atau melukiskan keadaan subjek atau objek penelitian (seseorang, lembaga, masyarakat, dan lain-lain) pada saat sekarang 
berdasarkan fakta-fakta yang tampak sebagaimana adanya (Nawawi, 2002). Teknik pengambilan sampel adalah total sampling dengan jumlah sampel 18 guru PAUD. Teknik pengumpulan data disebarkan melalui angket yang menggunakan skala likert dan skala guttman dengan alternatif jawaban iya atau tidak. Jumlah item keseluruhan sebanyak 15 buah item yang berkenaan dengan bagaimana persepsi guru terhadap penggunaan google classroom sebagai media belajar selama masa pandemic ini.

\section{Hasil Penelitian Dan Pembahasan}

Penelitian ini dilakukan kepada semua guru PAUD yang mengikuti pelatihan secara daring, dengan jumlah sampel sebanyak 18 orang guru PAUD.

\section{Tabel 1}

Data Populasi Guru PAUD

\begin{tabular}{|l|l|c|}
\hline \multicolumn{1}{|c|}{ No } & \multicolumn{1}{|c|}{ Kota } & Jumlah \\
\hline 1 & Medan & 9 \\
\hline 2 & Binjai & 9 \\
\hline Total & $\mathbf{1 8}$ \\
\hline
\end{tabular}

Berdasarkan tabel di atas, terlihat bahwa ada sebanyak 9 orang guru PAUD yang berasal dari Kota Medan dan 9 orang guru PAUD yang berasal dari Kota Binjai.

Tabel 2

Data Hasil Angket Yang Telah Dibagikan

\begin{tabular}{|c|c|c|}
\hline Keterangan & Jumlah & Persentase \\
\hline Perlu & 10 & $55 \%$ \\
\hline Cukup Perlu & 5 & $28 \%$ \\
\hline Tidak Perlu & 3 & $17 \%$ \\
\hline
\end{tabular}

Dari tabel 2 diatas, dapat dilihat bahwa kebutuhan guru dalam penggunaan google classroom sebagai media bantu dalam kegiatan belajar mengajar sangat perlu. Dari 18 sample guru, yang menyatakan kebutuhan perlu sebanyak 10 orang guru PAUD (55\%), 5 orang guru PAUD menyatakan cukup perlu (28\%) dan 3 orang guru PAUD menyatakan tidak perlu (17\%).

Dalam proses pembelajaran diperlukan alat/ media yang digunakan sebagai perantara antara guru dengan murid/ orangtua guna untuk memudahkan proses kegiatan belajar mengajar, baik dilaksmuridan di sekolah maupun dari rumah. Dari hasil angket di atas, google classroom dianggap perlu untuk digunakan oleh guru dalam proses pelaksanaan pembelajaran. 


\section{Simpulan}

Google classroom sesungguhnya dirancang untuk mempermudah interaksi antara guru PAUD dan orangtua/ murid dalam dunia maya. Classroom merupakan sebuah fitur yang efisien, mudah digunakan, dan membantu guru dalam mengelola tugas. Dengan Classroom, guru dapat membuat kelas, mendistribusikan tugas, memberi nilai, mengirim masukan, dan melihat semuanya di satu tempat. Guru juga dapat melihat perkembangan belajar murid dan mengetahui di mana dan kapan harus memberikan masukan tambahan. Sehingga dengan menggunakan google classroom memungkinkan alur komunikasi antara guru dengan murid/ orangtua menjadi lebih efektif.

Aplikasi Google Classroom layak digunakan sebagai media pembelajaran apalagi ditengah situasi pandemic seperti ini yang mengharuskan murid belajar dari rumah, karena penggunaan Google Classroom dalam proses belajar mengajar dapat membangkitkan keinginan, daya tarik, motivasi dan merangsang kegiatan belajar mengajar, selain itu Google Classroom juga dapat membantu murid maupun orangtua untuk mempermudah pemahan terhadap materi pelajaran yang diberikan oleh guru. Melalui google classroom juga guru menjadi terbantu untuk mengakomodir pembelajaran yang akan dan telah dilaksmuridan oleh murid.

Dengan demikian, dapat dinyatakan aplikasi ini berguna karena membantu memudahkan guru dan orangtua murid dalam melaksmuridan proses belajar mengajar.

\section{Daftar Pustaka}

Arsyad, Azhar. (2000). Media Pembelajaran. Jakarta:PT.RajaGrafindo Persada

Iskandar, dkk. 2020. Aplikasi Pembelajaran TIK. (online) .https://books.google.co.id/books?id=_LfQDwAAQBAJ\&pg=PA68\&d $\mathrm{q}=$ aplikasi+pembelajaran+tik\&hl=en\&sa=X\&ved=0ahUKEwilt66ZuZn pAhWUfH0KHfGcClEQ6AElKTAA\#v=onepage\&q=aplikasi\%20pem belajaran\%20tik\&f=false (diakses pada tanggal 15 September 2020, pukul 14.00 WIB).

Khairunnisa. 2020. Analisis Pemanfaatan Aplikasi Google Classroom Sebagai Media Pembelajarandalam Meningkatkan Motivasi Belajar Siswa. Skripsi. Umsu. Medan 